\title{
Is Osteopontin a Friend or Foe of Cell Apoptosis in Inflammatory Gastrointestinal and Liver Diseases?
}

\author{
Tomoya Iida (1), Kohei Wagatsuma, Daisuke Hirayama and Hiroshi Nakase * \\ Department of Gastroenterology and Hepatology, Sapporo Medical University School of Medicine, \\ Minami 1-jo Nishi 16-chome, Chuo-ku, Sapporo 060-8543, Japan; tomoya.iida.0306@gmail.com (T.I.); \\ waga_a05m@yahoo.co.jp (K.W.); d.hirayama@sapmed.ac.jp (D.H.) \\ * Correspondence: hiropynakase@gmail.com; Tel.: +81-11-611-2111; Fax: +81-11-611-2282
}

Received: 22 November 2017; Accepted: 19 December 2017; Published: 21 December 2017

\begin{abstract}
Osteopontin (OPN) is involved in a variety of biological processes, including bone remodeling, innate immunity, acute and chronic inflammation, and cancer. The expression of OPN occurs in various tissues and cells, including intestinal epithelial cells and immune cells such as macrophages, dendritic cells, and T lymphocytes. OPN plays an important role in the efficient development of $\mathrm{T}$ helper 1 immune responses and cell survival by inhibiting apoptosis. The association of OPN with apoptosis has been investigated. In this review, we described the role of OPN in inflammatory gastrointestinal and liver diseases, focusing on the association of OPN with apoptosis. OPN changes its association with apoptosis depending on the type of disease and the phase of disease activity, acting as a promoter or a suppressor of inflammation and inflammatory carcinogenesis. It is essential that the roles of OPN in those diseases are elucidated, and treatments based on its mechanism are developed.
\end{abstract}

Keywords: osteopontin; apoptosis; gastrointestinal; liver; inflammation; cacinogenesis

\section{Introduction}

Cancer epidemiologists have described three carcinogenesis factors: daily diet, smoking, and inflammation [1]. Although they have estimated that approximately $75 \%$ of cancers were due to those factors in 1980s, the percentage decreased to $43 \%$ in 2000s [1]. Among these three factors, inflammation is important because it does not involve lifestyle, unlike the other two factors.

Inflammation is a physiological response of the body in the attempt to remove harmful stimuli, including damaged cells, irritants, pathogens, and sterile injuries such as cancer, and to begin the healing process. Myeloid cells, including macrophages and neutrophils, are the first immune cells involved in inflammation and are abundant in the tumor microenvironment [2,3]. Fibroblasts are also closely related to inflammation, and they produce collagen and other extracellular matrix components in the tumor microenvironment, stimulating cancer cell proliferation and angiogenesis. Various cytokines, chemokines, other molecules, including osteopontin (OPN), released from immune cells, and fibroblasts relate to the process of inflammatory carcinogenesis [4-7].

OPN is an extracellular matrix protein. It was identified in 1985 by Heingard et al., as a sialoprotein derived from bovine bone matrix [8]. OPN was also referred to as secreted phosphoprotein 1 (SPP1) and early T lymphocyte activation-1 (ETA-1). This plurality of names reflects the involvement of OPN in multiple physiological and pathological processes $[9,10]$. OPN belongs to the small integrin binding ligand $N$-linked glycoprotein (SIBLING) family [11]. Although this protein is produced as an approximately $32-\mathrm{kDa}$, the molecular mass actually ranges from 45 to $75 \mathrm{kDa}$ because of extensive posttranslational modifications [12]. OPN is involved in a variety of biological processes, including bone remodeling, innate immunity, acute and chronic inflammation, and cancer [13,14]. 
OPN is expressed as a secreted OPN (sOPN) or an intracellular OPN (iOPN) isoform generated from different OPN translational initiation sites [15]. sOPN is an extracellular protein and relates to various physiologic and pathological events, including immune regulation [16], inflammation [17], tumor progression, and metastasis [18]. On the contrary, iOPN is predominantly present in the cytoplasm and lacks the N-terminal signal sequence of sOPN [15]. The expression of OPN is observed in various tissues and cells, including intestinal epithelial and immune cells such as macrophages, dendritic cells (DCs), and T lymphocytes [19].

OPN plays an important role in efficient development of T helper 1 (Th1) immune responses [20] and cell survival by inhibiting apoptosis [21]. The association of OPN with apoptosis has been elucidated. In this review, we described the role of OPN in inflammatory gastrointestinal (GI) and liver diseases, focusing on its association with apoptosis.

\section{The Role of OPN in Immune Cells, Focusing on Its Association with Inflammation and Apoptosis}

OPN has specific roles in each immune cell. OPN plays an important role in acute and chronic inflammation. Figure 1 shows how OPN is involved in inflammation and apoptosis related to each immune cell.

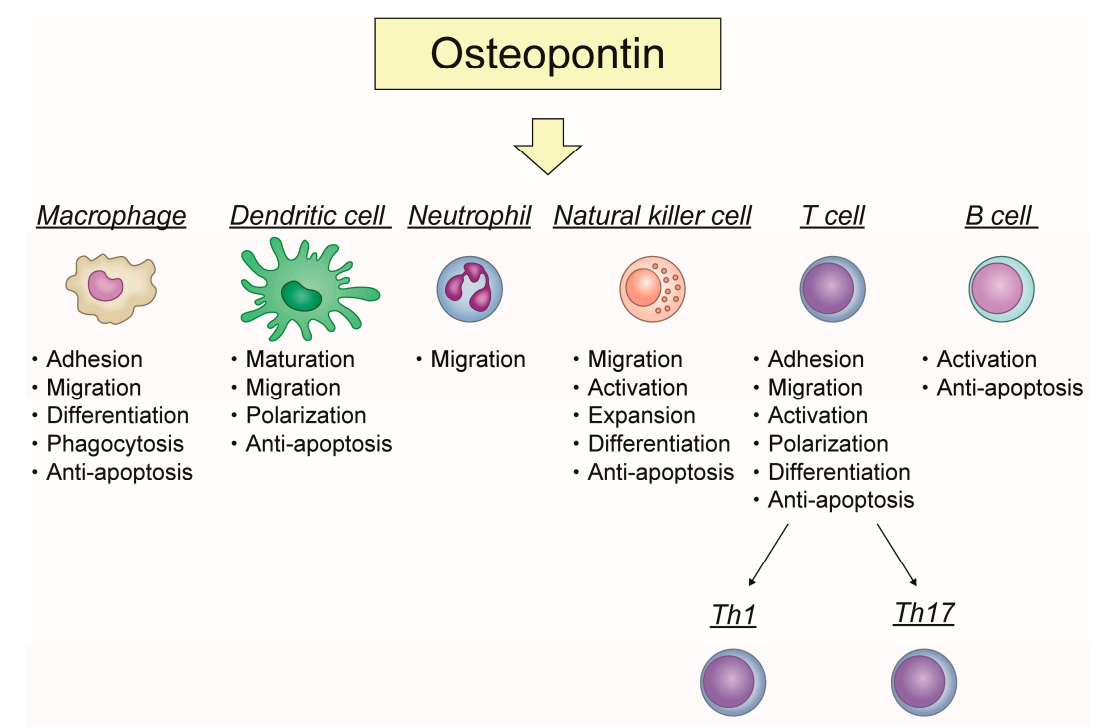

Figure 1. The role of osteopontin in immune cells focusing on the relationship between inflammation and apoptosis.

\subsection{Macrophage}

Primarily, OPN not only stimulates migration, accumulation, and retention of macrophages at sites of injury but can also modulate their cytokine production by promoting Th1 cell-mediated immunity and stimulating their differentiation from monocytes in both acute and chronic inflammation. OPN controls several immune cell functions, including monocyte adhesion, migration, differentiation, and phagocytosis. OPN has multiple functional adhesive motifs, which allow interactions with various cells, including smooth muscle, endothelial, and inflammatory cells. One of the representative adhesive motifs is the Arg-Gly-Asp (RGD) integrin binding domain. The integrin binding domain of OPN mediates interactions via $\alpha_{\mathrm{v}} \beta_{1}, \alpha_{\mathrm{v}} \beta_{3}, \alpha_{\mathrm{v}} \beta_{5}, \alpha_{\mathrm{v}} \beta_{6}, \alpha_{5} \beta_{1}$, and $\alpha_{8} \beta_{1}$ integrins [22,23]. In addition, the adjacent Ser-Val-Val-Tyr-Gly-Leu-Arg (SVVYGLR) sequence interacts with $\alpha_{9} \beta_{1}, \alpha_{4} \beta_{1}$, and $\alpha_{4} \beta_{7}$ integrins, which are present on the surface of immune cells such as macrophages, T-cells, and neutrophils [24]. The interaction of OPN, not only with $\alpha_{4}$ and $\alpha_{9}$ integrins but also with CD44, influences migration of macrophages. Of note, OPN inhibits macrophage apoptosis by interacting with $\alpha_{4}$ integrin and CD44 $[25,26]$. Moreover, iOPN increases nuclear factor kappa-light-chain-enhancer 
of activated B cells (NF- $\mathrm{kB}$ ) activation through phosphorylation and degradation of nuclear factor of kappa light polypeptide gene enhancer in B-cells inhibitor, $\alpha(\operatorname{I\kappa } B \alpha)$ by inducing the IкB kinase $\alpha / \beta$ $(\mathrm{IKK} \alpha / \beta)$ activity $[27,28]$.

\subsection{Dendritic Cell (DC)}

OPN plays a key role in DC maturation, migration, and polarization [29]. The expression of OPN in immature DCs is higher than in mature DCs. Therefore, OPN works as an autocrine and/or paracrine signal for DC maturation [30]. OPN is involved in the mechanism of DC migration by interacting with $\alpha_{\mathrm{v}}$ integrin and CD44 [31]. In addition, OPN acts as a pro-survival signal for DCs, because OPN blocking results in their decreased expression of costimulatory and major histocompatibility complex (MHC) class II molecules, and increased apoptosis [30,31].

\subsection{Neutrophil}

OPN induces neutrophil migration. It is dependent on ERK and P38 MAP kinases activation [32]. OPN seems to affect neutrophil recruitment via integrin- $\alpha_{v}$-dependent suppression of CXC chemokine receptor 2 (CXCR2) internalization in neutrophils $[33,34]$. No studies demonstrating the association of OPN with apoptosis in neutrophils are available.

\subsection{Natural Killer (NK) Cell}

OPN plays a key role in increasing NK cell migration and activation. iOPN regulates homeostasis and function in NK cells. The expression of iOPN in NK cells is essential for successful navigation through the contraction phase of expansion and generation of long-lived NK cells with increased functionality [35]. As for the association of NK cells with apoptosis, NK cell-induced apoptosis in tubular epithelial cells has been reported as well as the contribution to renal ischemia reperfusion injury [36]. A beneficial role of blocking OPN expression in renal ischemia-reperfusion injury associated with NK cell-mediated downregulation of inflammatory cytokines and chemokines has been reported, demonstrating that the histologic architecture and apoptosis of renal tissue improved in anti-OPN antibody-treated mice [37]. Moreover, deficient expression of iOPN in NK cells causes impaired expansion and increased apoptosis of these cells following stimulation with interleukin 15 (IL-15), resulting in defective immune response to viral infection and tumor [38].

\subsection{T Cell}

OPN is involved in Th cell polarization by enhancing Th1 and Th17 differentiation and inhibiting Th2 cytokine expression. A study reported a relationship between iOPN and T follicular helper (TFH) [39]. OPN is also known as ETA-1 due to its high expression in activated T cells. It has been shown that an anti-OPN antibody promoted apoptosis of activated $\mathrm{T}$ cells, particularly CD4+ T cells, by inhibiting activation of NF- $\mathrm{kB}$ in a model of rheumatoid arthritis (RA) [40].

\subsection{B Cell}

OPN works as a polyclonal B-cell activator. OPN stimulates immunoglobulin (Ig) production by $B$ cells in vitro. In addition, it was reported that overexpressing OPN induced elevated serum levels of several isotypes of Ig in vivo [41,42]. OPN is related to autoimmune diseases such as RA, systemic lupus erythematosus [43,44], and multiple sclerosis (MS) [45,46]. In an MS mouse model, B-cell activating factor (BAFF) induces B-cell lymphoma 2 (BCL-2) expression in T cells by upregulating OPN secretion from B cells [47].

\section{The Association of OPN with Apoptosis in Inflammatory GI and Liver Diseases}

OPN has an important role in various inflammatory GI and liver diseases (Figure 2). 


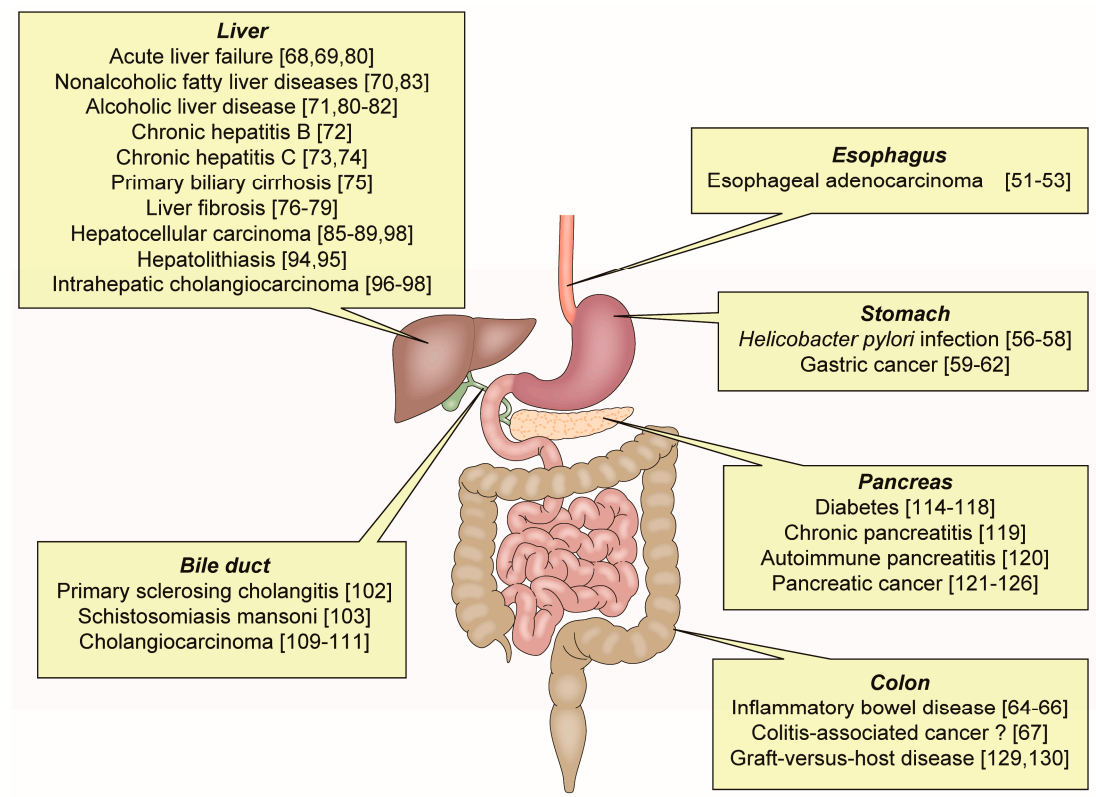

Figure 2. Inflammatory gastrointestinal and liver diseases related to osteopontin.

Apoptosis is an essential process for maintaining homeostasis in normal tissues and is deeply connected with inflammation and carcinogenesis [48]. In inflammatory GI and liver diseases, OPN is associated with apoptosis via various molecular mechanisms (Figure 3).

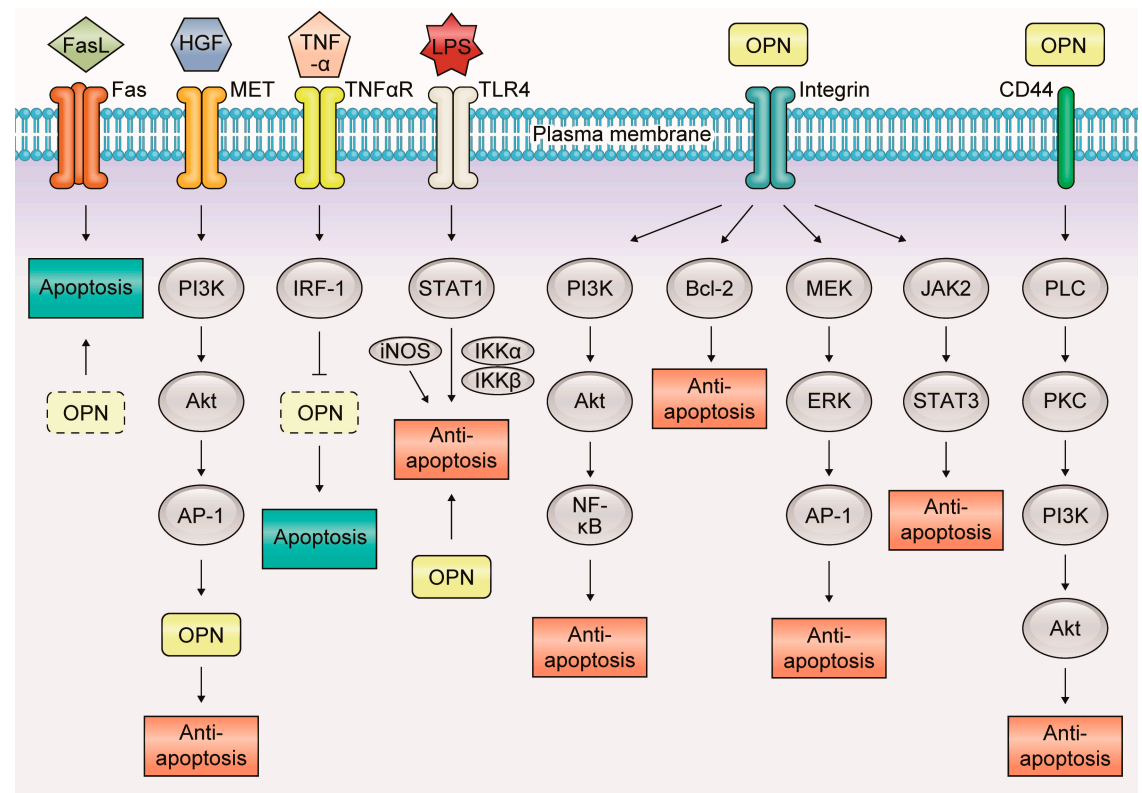

Figure 3. Molecular mechanisms of the relationship between osteopontin and apoptosis in inflammatory gastrointestinal and liver diseases. In inflammatory gastrointestinal and liver diseases, OPN is associated with apoptosis via various molecular mechanisms. OPN mainly plays an anti-apoptotic role in many signaling pathways interacting with each receptor.

\subsection{Esophageal Adenocarcinoma (EAC)}

EAC is a malignant tumor caused by chronic inflammation. Chronic gastroesophageal reflux disease is a major risk factor for the development of Barrett's esophagus, which could lead to EAC $[49,50]$. The prognosis of EAC patients with the expression of OPN is poor [51]. The expression 
of OPN is considerably elevated in EAC compared to Barret's esophagus and low- or high-grade dysplasia. The same study has demonstrated that all five isoforms of OPN (OPNa, OPNb, OPNc, OPN4, and OPN5) were co-overexpressed in the majority of primary EACs and that individual OPN isoforms showed distinct phenotypes, yet acting collectively in tumor invasion and dissemination in EAC/OPN cell models [52]. In addition, increased expression of multiple genes such as matrix metalloproteinases (MMPs) and OPN in the MET pathway associated with invasive growth was observed in EACs. Treatment of EAC-derived cell lines with geldanamycin, an inhibitor of tyrosine kinases, including MET receptor kinases, reduces cell migration and induces EAC cell apoptosis. These results indicate that MET pathway, which is correlated with OPN, upregulates EAC cell migration and decreases EAC cell apoptosis [53].

\subsection{Helicobacter pylori Infection and Gastric Cancer (GC)}

H. pylori is the well-recognized cause of GC and has been classified by World Health Organization as group I carcinogen. $H$. pylori-infected patients develop GC via multistep processes, including chronic gastritis, atrophic gastritis, intestinal metaplasia (IM), dysplasia, and ultimately GC [54,55]. OPN contributes to immune escape of $H$. pylori via inhibition of inducible nitric oxide synthase (iNOS) production by macrophage [56]. A study including $105 \mathrm{H}$. pylori-infected patients has shown that increased expression of gastric OPN during $H$. pylori infection correlated with a more severe gastric inflammation and the presence of IM [57]. A study including H. pylori-infected patients with or without IM has also shown that OPN polymorphisms predisposed to IM development in $H$. pylori-infected males [58].

Several studies have reported increased expression of OPN in GC. A study has reported that the pro-survival and anti-apoptosis activities of OPN in GC cells were mediated in part through phosphoinositide 3-kinase (PI3K)/AKT pathway via $\alpha_{\mathrm{v}} \beta_{3}$ integrins [59]. PI3K/AKT pathway and hypoxia-inducible factor- 1 are involved in the tumor-promoting function of OPN, which induces pro-survival and anti-apoptosis signaling in GCs after the survival pathway is activated [60]. In GC, the NF- $\mathrm{kB}$ pathway is also crucial for cell survival via initiation of the gene expression of anti-apoptotic factors [61]. In addition, in OPN-knockout (KO) mice treated with $N$-methyl- $N$-nitrosourea and infected with $\mathrm{H}$. pylori, the loss of OPN decreased H. pylori-induced gastric carcinogenesis by suppressing pro-inflammatory immune response and augmenting signal transducer and activator of transcription 1 (STAT1) and iNOS-mediated apoptosis of gastric epithelial cells [62].

\subsection{Inflammatory Bowel Disease (IBD) and Colitis-Associated Cancer (CAC)}

IBD is a chronic inflammatory disease involving idiopathic inflammation, mainly in the GI tract. It comprises ulcerative colitis (UC) and Crohn's disease (CD) which cause chronic intestinal inflammation, mucosal damage, and epithelial barrier dysfunction. Various cytokines, including tumor necrosis factor- $\alpha$ (TNF- $\alpha$ ), are related to the pathophysiology of IBD. TNF- $\alpha$ is a main therapeutic target for IBD. TNF- $\alpha$ induces the transcription factor interferon regulatory factor-1 (IRF-1) in intestinal epithelial cells in vitro. Induction of IRF-1 is associated with epithelial cell apoptosis by OPN suppression [63]. Previous studies have shown that OPN protected from acute colitis but not from chronic colitis in an experimental colitis model $[64,65]$. It has also been reported that OPN-KO mice exhibited considerably decreased disease activity compared to wild-type (WT) mice as evidenced by reduced rectal bleeding, weight loss, and histological intestinal injury [66]. These paradoxical data reflect the possibility that the role of OPN may be different depending on the type of disease and the disease phase. It is also possible that the role of OPN differs in epithelium and immune cells.

There is no report showing a direct association of OPN with CAC. IRF-1 is related to OPN and apoptosis in IBD [63]. In dextran sulfate sodium (DSS)-treated mice, more colonic dysplasia was observed in IRF-1-KO mice than in WT mice. In addition, microarray analysis comparing colonic gene expression in IRF-1-KO mice and WT mice revealed decreased expression of caspases and tumor 
suppressor genes in the IRF-1-KO mice [67]. Further studies are needed to elucidate the possible association of OPN with CACf.

\subsection{Liver Diseases}

In the liver, OPN interacts with integrins, CD44, vimentin, and MyD88 signaling pathway, inducing infiltration and migration of immune cells. OPN is a chemoattractant for macrophages and neutrophils during injury in inflammatory liver diseases.

OPN is involved in many liver diseases such as acute liver failure (ALF) [68,69], non-alcoholic fatty liver disease (NAFLD) [70], alcoholic liver disease [71], chronic hepatitis B [72], chronic hepatitis C [73,74], primary biliary cirrhosis [75], and liver fibrosis [76-79]. However, the roles of OPN in such liver diseases are still controversial. While OPN interacts with neutrophil $\alpha_{4} \beta_{1}$ and $\alpha_{9} \beta_{1}$ integrins, contributing to hepatic neutrophil transmigration and activation, leading to further injury in a rat alcoholic steatohepatitis model [80], OPN deficiency does not prevent but promotes alcoholic neutrophilic hepatitis in mice [81]. In addition, a protective role of OPN in liver has been reported. Transgenic expression of OPN in hepatocytes reduces alcohol-induced hepatic steatosis, balloon cell degeneration, lipid peroxidation, inflammation, and plasma alanine aminotransferase (ALT) activity [82]. A few studies have reported the association of OPN with apoptosis in a rat liver disease model. A study has shown that the expression of BCL-2 was downregulated in ALF and NAFLD, indicating that OPN participated in promoting apoptosis [83]. In addition, OPN enhanced inflammation and cell proliferation, attenuated cell apoptosis, and ultimately facilitated liver regeneration at the termination stage of liver regeneration [84].

OPN plays a crucial role in the oncogenesis of hepatocellular carcinoma (HCC), and overexpression of OPN is positively correlated with tumor progression [85]. Another study has also reported that overexpression of OPN led to intrahepatic metastasis, early recurrence, and poorer prognosis of surgically resected HCC [86,87]. There are several studies showing the association of OPN with HCC apoptosis. In HCC cell line, downregulation of OPN suppresses growth and metastasis of HCC by induction of apoptosis. The same study has reported that OPN silencing in HCC cells resulted in suppression of $\alpha_{\mathrm{v}}, \beta_{1}$, and $\beta_{3}$ integrin expression, inhibition of NF- $\mathrm{kB}$ signaling activation, and blockade of BCL-2/B-cell lymphoma-extra large (BCL-XL) and X-linked inhibitor of apoptosis protein (XIAP) expression, increase of BAX expression, inducing mitochondria-mediated apoptosis [88]. In OPN-KO mice, hepatic carcinogenesis is considerably inhibited by OPN deficiency, accompanied by the increase of apoptotic cell death. The same study has also shown that OPN was an important factor for inducing c-Jun-mediated epidermal growth factor receptor transcription, resulting in the inhibition of apoptotic cell death [89].

In addition, hepatolithiasis is an important factor of intrahepatic cholangiocarcinoma (ICC) [90-93]. There are only few studies investigating the association of OPN and hepatolithiasis-related apoptosis [94,95]. Data from 17 hepatic resection specimens with hepatolith have shown positive immunostaining results for OPN in the cytoplasm of the epithelial cells of stone-containing intrahepatic bile ducts and intramural and extramural glands, and in stones. The results have suggested that OPN from the intrahepatic bile ducts and peribiliary glands played a role in the formation of intrahepatic stones [94]. In addition, a study on surgically resected specimens from 73 patients with ICC has shown negative correlation between the expression of OPN and tumor aggressiveness and clinical outcome [96]. On the contrary, another study, using tissue microarray analysis, indicated a positive correlation between the expression of OPN and poor prognosis [97]. There are few reports on the association of OPN and ICC apoptosis. The inhibition of microRNA-21, upregulated in HCC and ICC, reduces liver fibrosis and prevents tumor development by inducing apoptosis of CD24+ progenitor cells [98].

\subsection{Bile Duct Diseases}

The etiology of CC is typically associated with chronic biliary inflammation, which can be observed in primary sclerosing cholangitis (PSC), pancreaticobiliary maljunction, or infection, 
including hepatitis B virus (HBV) and HCV infections [99-101]. There are few reports on the association of OPN with bile duct diseases. In PSC mice with 3, 5-diethoxycarbonyl-1, 4-dihydrocollidine-induced sclerosing cholangitis, the genetic loss of neither OPN nor TNF- $\alpha$ receptor- 1 considerably affects the pathogenesis of sclerosing cholangitis, ductular reaction, and biliary fibrosis [102]. With regards to a rare disease, schistosome-induced cholangiocyte proliferation and OPN secretion correlate with fibrosis and portal hypertension in human and murine Schistosomiasis mansoni [103]. On the other hand, several molecular mechanisms of CC carcinogenesis have been reported, including the KRAS/RAF/MEK/mitogen-activated protein kinase (MAPK) [104], IL-6/signal transducer and activator of transcription 3 (STAT3) [105,106], transforming growth factor $\beta$ (TGF- $\beta$ )/SMAD [107], and TNF- $\alpha /$ Snail pathways [108]. However, only few studies have been conducted to investigate the relationship between OPN and CC $[109,110]$. A study has reported that, in correlation with the upregulation in CC cells and the tumor stroma, serum levels of OPN were elevated in patients with CC compared to in healthy controls and patients with PSC [111]. There is no report directly investigating the association of OPN with apoptosis in biliary tract diseases. However, CC is related to TGF- $\beta$-induced apoptosis [112]. In addition, MCL-1, which is a member of the BCL-2 protein family involved in the regulation of apoptotic cell death, is upregulated in CC cell lines via an IL-6/Janus kinase (JAK)/STAT-dependent pathway [113]. Further studies are needed to investigate the association of OPN with apoptosis in bile duct diseases.

\subsection{Pancreatic Diseases}

OPN is associated with diabetes closely related to insulin and glucagon secretion $[114,115]$. The expression of OPN is accelerated in vascular smooth muscle cells of rats because of the protein kinase $C$ and hexosamine pathway activation-induced high glucose concentration [114]. Oxidant stress is also involved in the accelerated expression of OPN in vascular smooth muscle cells of rats because of the high glucose concentration [115]. In addition, OPN inhibits cytokine-induced apoptosis via reduction of NO and iNOS levels [116], and stimulates $\beta$-cell proliferation [117]. $\beta$-cell proliferative and anti-apoptotic roles have been described for glucose-dependent insulinotropic polypeptide, in addition to its action as an incretin hormone [118].

OPN is expressed in acinar cells, ductal cells, and invading macrophages in chronic pancreatitis (CP) specimens but not in normal pancreas [119]. In an autoimmune pancreatitis (AIP) model of WBN/Kob rats, the expression of OPN in centroacinar cells in CP with calcification and in AIP is considerably greater than that in normal pancreas [120]. OPN is also used as a discriminating marker for pancreatic cancer (PC) and CP [121]. OPN influences the invasiveness of PC cells and increases in neoplastic and inflammatory conditions [122]. A meta-analysis has shown that an elevated serum OPN level might be used as a promising diagnostic tool for early identification of PC [123]. In addition, a recent study has reported that high glucose levels accelerated cell proliferation and increased the secretion of OPN in human pancreatic duct epithelial cells [124]. However, another study has reported that the presence of OPN in PC might have a protective effect independent of tumor stage [125], and a recent study has concluded that the relationship between OPN and PC remained unclear [126]. There are no reports which directly show the association of OPN with apoptosis in PC.

\subsection{Graft-Versus-Host Disease (GVHD)}

GVHD is one of the major complications after allogeneic hematopoietic stem cell transplantation (HSCT). Acute GVHD is characterized by the infiltration of donor T lymphocytes that are specific against host antigens and epithelial cell apoptosis [127,128]. A study has indicated that OPN exacerbated GVHD by stimulating CD8+ T cells and that anti-OPN antibody treatment inhibited the development of acute GVHD in a mouse model [129]. In addition, OPN deficiency in donor cells affects the onset of acute Gl GVHD by regulating apoptosis of the intestinal cells via the Fas-Fas ligand pathway [130]. This discrepancy may be explained by differences in models and the observational period after HSCT. 
Inflammatory gastrointestinal and liver diseases related to osteopontin-induced apoptosis were summarized in Table 1.

Table 1. Inflammatory gastrointestinal and liver diseases related to osteopontin-induced apoptosis.

\begin{tabular}{cccc}
\hline Organ & Disease & Osteopontin-Induced Apoptosis & Reference \\
\hline Esophagus & Esophageal adenocarcinoma & $\downarrow$ & {$[52,53]$} \\
\hline Stomach & Gastric caner & $\downarrow$ & {$[59-62]$} \\
\hline \multirow{3}{*}{ Colon } & Inflammatory bowel disease & $\downarrow$ & {$[63]$} \\
& Colitis-associated cancer & $\downarrow ?$ & {$[63,67]$} \\
& Graft-versus-host disease & $\uparrow / \downarrow$ & {$[129] /[130]$} \\
\hline \multirow{2}{*}{ Liver } & Acute liver failure & $\uparrow$ & {$[83]$} \\
& Nonalcoholic fatty liver disease & $\uparrow$ & {$[83]$} \\
& Hepatocellular carcinoma & $\downarrow$ & {$[88,89]$} \\
\hline Bile duct & Cholangiocarcinoma & $\downarrow ?$ & {$[113]$} \\
\hline
\end{tabular}

$\uparrow:$ upregulated, $\downarrow$ : downregulated, ?: possibility.

\section{Conclusions}

In this review, we showed the role of OPN in inflammatory GI and liver diseases in association with apoptosis. OPN changes its association with apoptosis depending on the type of disease and the phase of disease activity, and acts as a promoter or a suppressor in inflammation and inflammatory carcinogenesis. It is essential that the roles of OPN in those diseases are elucidated, and treatments based on its mechanism are developed.

Acknowledgments: Health and Labour Sciences Research Grants for research on intractable diseases from the Ministry of Health, Labour and Welfare of Japan (Investigation and Research for intractable Inflammatory Bowel Disease) and Japan Society for the Promotion of Science (JSPS) Grants-in-Aid for Scientific Research (KAKENHI) Grant Number JP17J02428.

Author Contributions: Tomoya Iida, Kohei Wagatsuma, Daisuke Hirayama and Hiroshi Nakasewere involved in the planning and collecting of the data for this review, and in drafting/editing the manuscript. All the above-mentioned authors have approved the final draft of the manuscript.

Conflicts of Interest: The authors declare no conflict of interest. The funders of the study had no role in the study design, data collection, data analysis, data interpretation, or writing of the report.

\section{References}

1. Global Action against Cancer-Updated Version; World Health Organization and International Union against Cancer: Geneva, Switzerland, 2005; p. 12.

2. Galdiero, M.R.; Bonavita, E.; Barajon, I.; Garlanda, C.; Mantovani, A.; Jaillon, S. Tumor associated macrophages and neutrophils in cancer. Immunobiology 2013, 218, 1402-1410. [CrossRef] [PubMed]

3. Ruffel, B.; Coussens, L.M. Macrophages and therapeutic resistance in cancer. Cancer Cell 2015, 27, 462-472. [CrossRef] [PubMed]

4. Shalapour, S.; Karin, M. Immunity, inflammation, and cancer: An eternal fight between good and evil. J. Clin. Investig. 2015, 125, 3347-3355. [CrossRef] [PubMed]

5. Grivennikov, S.I.; Greten, F.R.; Karin, M. Immunity, inflammation, and cancer. Cell 2010, 140, 883-899. [CrossRef] [PubMed]

6. Chang, H.Y.; Sneddon, J.B.; Alizadeh, A.A.; Sood, R.; West, R.B.; Montgomery, K.; Chi, J.T.; van de Rijn, M.; Botstein, D.; Brown, P.O. Gene expression signature of fibroblast serum response predicts human cancer progression: Similarities between tumors and wounds. PLoS Biol. 2004, 2, E7. [CrossRef] [PubMed]

7. Erez, N.; Truitt, M.; Olson, P.; Arron, S.T.; Hanahan, D. Cancer-associated fibroblasts are activated in incipient neoplasia to orchestrate tumor-promoting inflammation in an NF-kB-dependent manner. Cancer Cell 2010, 17, 135-147. [CrossRef] [PubMed] 
8. Franzen, A.; Heinegard, D. Isolation and characterization of two sialoproteins present only in bone calcified matrix. Biochem. J. 1985, 232, 715-724. [CrossRef] [PubMed]

9. Vaschetto, R.; Nicola, S.; Olivieri, C.; Boggio, E.; Piccolella, F.; Mesturini, R.; Damnotti, F.; Colombo, D.; Navalesi, P.; Della Corte, F.; et al. Serum levels of osteopontin are increased in SIRS and sepsis. Intensive Care Med. 2008, 34, 2176-2184. [CrossRef] [PubMed]

10. Castello, L.M.; Raineri, D.; Salmi, L.; Clemente, N.; Vaschetto, R.; Quaglia, M.; Garzaro, M.; Gentilli, S.; Navalesi, P.; Cantaluppi, V.; et al. Osteopontin at the Crossroads of Inflammation and Tumor Progression. Mediat. Inflamm. 2017, 2017, 4049098. [CrossRef] [PubMed]

11. Fisher, L.W.; Torchia, D.A.; Fohr, B.; Young, M.F.; Fedarko, N.S. Flexible structures of SIBLING proteins, bone sialoprotein, and osteopontin. Biochem. Biophys. Res. Commun. 2007, 280, 460-465. [CrossRef] [PubMed]

12. Kazanecki, C.C.; Uzwiak, D.J.; Denhardt, D.T. Control of osteopontin signaling and function by post-translational phosphorylation and protein folding. J. Cell. Biochem. 2007, 102, 912-924. [CrossRef] [PubMed]

13. Shevde, L.A.; Samant, R.S. Role of osteopontin in the pathophysiology of cancer. Matrix Biol. 2014, 37, 131-141. [CrossRef] [PubMed]

14. Denhardt, D.T.; Noda, M.; O’Regan, A.W.; Pavlin, D.; Berman, J.S. Osteopontin as a means to cope with environmental insults: Regulation of inflammation, tissue remodeling, and cell survival. J. Clin. Investig. 2001, 107, 1055-1061. [CrossRef] [PubMed]

15. Shinohara, M.L.; Kim, H.J.; Kim, J.H.; Garcia, V.A.; Cantor, H. Alternative translation of osteopontin generates intracellular and secreted isoforms that mediate distinct biological activities in dendritic cells. Proc. Natl. Acad. Sci. USA 2008, 105, 7235-7239. [CrossRef] [PubMed]

16. Wang, K.X.; Denhardt, D.T. Osteopontin: Role in immuneregulation and stress responses. Cytokine Growth Factor Rev. 2008, 19, 333-345. [CrossRef] [PubMed]

17. Ramaiah, S.K.; Rittling, S. Pathophysiological role of osteopontin in hepatic inflammation, toxicity, and cancer. Toxicol. Sci. 2008, 103, 4-13. [CrossRef] [PubMed]

18. Rittling, S.R.; Chambers, A.F. Role of osteopontin in tumour progression. Br. J. Cancer 2004, 90, $1877-1881$. [CrossRef] [PubMed]

19. Brown, L.F.; Berse, B.; Van de Water, L.; Papadopoulos-Sergiou, A.; Perruzzi, C.A.; Manseau, E.J.; Dvorak, H.F.; Senger, D.R. Expression and distribution of osteopontin in human tissues: Widespread association with luminal epithelial surfaces. Mol. Biol. Cell 1992, 3, 1169-1180. [CrossRef] [PubMed]

20. Ashkar, S.; Weber, G.F.; Panoutsakopoulou, V.; Sanchirico, M.E.; Jansson, M.; Zawaideh, S.; Rittling, S.R.; Denhardt, D.T.; Glimcher, M.J.; Cantor, H. Eta-1 (osteopontin): An early component of type-1 (cell-mediated) immunity. Science 2000, 287, 860-864. [CrossRef] [PubMed]

21. Zhang, H.; Guo, M.; Chen, J.H.; Wang, Z.; Du, X.F.; Liu, P.X.; Li, W.H. Osteopontin knockdown inhibits $\alpha \mathrm{v}, \beta 3$ integrin-induced cell migration and invasion and promotes apoptosis of breast cancer cells by inducing autophagy and inactivating the PI3K/Akt/mTOR pathway. Cell Physiol. Biochem. 2014, 33, 991-1002. [CrossRef] [PubMed]

22. Liaw, L.; Skinner, M.P.; Raines, E.W.; Ross, R.; Cheresh, D.A.; Schwartz, S.M.; Giachelli, C.M. The adhesive and migratory effects of osteopontin are mediated via distinct cell surface integrins. Role of alpha v beta 3 in smooth muscle cell migration to osteopontin in vitro. J. Clin. Investig. 1995, 95, 713-724. [CrossRef] [PubMed]

23. Yokosaki, Y.; Tanaka, K.; Higashikawa, F.; Yamashita, K.; Eboshida, A. Distinct structural requirements for binding of the integrins $\alpha v \beta 6, \alpha v \beta 3, \alpha v \beta 5, \alpha 5 \beta 1$ and $\alpha 9 \beta 1$ to osteopontin. Matrix Biol. 2005, 24, 418-427. [CrossRef] [PubMed]

24. Green, P.M.; Ludbrook, S.B.; Miller, D.D.; Horgan, C.M.; Barry, S.T. Structural elements of the osteopontin SVVYGLR motif important for the interaction with $\alpha(4)$ integrins. FEBS Lett. 2001, 503, 75-79. [CrossRef]

25. Marcondes, M.C.; Poling, M.; Watry, D.D.; Hall, D.; Fox, H.S. In vivo osteopontin-induced macrophage accumulation is dependent on CD44 expression. Cell. Immunol. 2008, 254, 56-62. [CrossRef] [PubMed]

26. Lund, S.A.; Wilson, C.L.; Raines, E.W.; Tang, J.; Giachelli, C.M.; Scatena, M. Osteopontin mediates macrophage chemotaxis via $\alpha 4$ and $\alpha 9$ integrins and survival via the $\alpha 4$ integrin. J. Cell. Biochem. 2013, 114, 1194-1202. [CrossRef] [PubMed] 
27. Das, R.; Philip, S.; Mahabeleshwar, G.H.; Bulbule, A.; Kundu, G.C. Osteopontin: It's role in regulation of cell motility and nuclear factor kB-mediated urokinase type plasminogen activator expression. IUBMB Life 2005, 57, 441-447. [CrossRef] [PubMed]

28. Viatour, P.; Merville, M.P.; Bours, V.; Chariot, A. Phosphorylation of NF- $\kappa$ B and IкB proteins: Implications in cancer and inflammation. Trends Biochem. Sci. 2005, 30, 43-52. [CrossRef] [PubMed]

29. Renkl, A.C.; Wussler, J.; Ahrens, T.; Thoma, K.; Kon, S.; Uede, T.; Martin, S.F.; Simon, J.C.; Weiss, J.M. Osteopontin functionally activates dendritic cells and induces their differentiation toward a Th1-polarizing phenotype. Blood 2005, 106, 946-955. [CrossRef] [PubMed]

30. Kawamura, K.; Iyonaga, K.; Ichiyasu, H.; Nagano, J.; Suga, M.; Sasaki, Y. Differentiation, maturation, and survival of dendritic cells by osteopontin regulation. Clin. Diagn. Lab. Immunol. 2005, 12, 206-212. [CrossRef] [PubMed]

31. Weiss, J.M.; Renkl, A.C.; Maier, C.S.; Kimmig, M.; Liaw, L.; Ahrens, T.; Kon, S.; Maeda, M.; Hotta, H.; Uede, T.; et al. Osteopontin is involved in the initiation of cutaneous contact hypersensitivity by inducing Langerhans and dendritic cell migration to lymph nodes. J. Exp. Med. 2001, 194, 1219-1229. [CrossRef] [PubMed]

32. Hirano, Y.; Azi, M.; Yang, W.L.; Wang, Z.; Zhou, M.; Ochani, M.; Khader, A.; Wang, P. Neutralization of osteopontin attenuates neutrophil migration in sepsis-induced acute lung injury. Crit. Care 2015, 19, 53. [CrossRef] [PubMed]

33. Koh, A.; da Silva, A.P.; Bansal, A.K.; Bansal, M.; Sun, C.; Lee, H.; Glogauer, M.; Sodek, J.; Zohar, R. Role of osteopontin in neutrophil function. Immunology 2007, 122, 466-475. [CrossRef] [PubMed]

34. Singh, R.; Hui, T.; Matsui, A.; Allahem, Z.; Johnston, C.D.; Ruiz-Torruella, M.; Rittling, S.R. Modulation of infection-mediated migration of neutrophils and CXCR2 trafficking by osteopontin. Immunology 2017, 150, 74-86. [CrossRef] [PubMed]

35. Leavenworth, J.W.; Verbinnen, B.; Wang, Q.; Shen, E.; Cantor, H. Intracellular osteopontin regulates homeostasis and function of natural killer cells. Proc. Natl. Acad. Sci. USA 2015, 112, 494-499. [CrossRef] [PubMed]

36. Zhang, Z.X.; Shek, K.; Wang, S.; Huang, X.; Lau, A.; Yin, Z.; Sun, H.; Liu, W.; Garcia, B.; Rittling, S.; et al. Osteopontin expressed in tubular epithelial cells regulates NK cell-mediated kidney ischemia reperfusion injury. J. Immunol. 2010, 185, 967-973. [CrossRef] [PubMed]

37. Cen, C.; Aziz, M.; Yang, W.L.; Nicastro, J.M.; Coppa, G.F.; Wang, P. Osteopontin Blockade Attenuates Renal Injury After Ischemia Reperfusion by Inhibiting NK Cell Infiltration. Shock 2017, 47, 52-60. [CrossRef] [PubMed]

38. Fan, X.; He, C.; Jing, W.; Zhou, X.; Chen, R.; Cao, L.; Zhu, M.; Jia, R.; Wang, H.; Guo, Y.; et al. Intracellular osteopontin inhibits toll-like receptor signaling and impedes liver carcinogenesis. Cancer Res. 2015, 75, 86-97. [CrossRef] [PubMed]

39. Leavenworth, J.W.; Verbinnen, B.; Yin, J.; Huang, H.; Cantor, H. A p85 $\alpha$-osteopontin axis couples the receptor ICOS to sustained Bcl-6 expression by follicular helper and regulatory T cells. Nat. Immunol. 2015, 16, 96-106. [CrossRef] [PubMed]

40. Fan, K.; Dai, J.; Wang, H.; Wei, H.; Cao, Z.; Hou, S.; Qian, W.; Li, B.; Zhao, J.; Xu, H.; et al. Treatment of collagen-induced arthritis with an anti-osteopontin monoclonal antibody through promotion of apoptosis of both murine and human activated T cells. Arthritis Rheum. 2008, 58, 2041-2052. [CrossRef] [PubMed]

41. Lampe, M.A.; Patarca, R.; Iregui, M.V.; Cantor, H. Polyclonal B cell activation by the Eta-1 cytokine and the development of systemic autoimmune disease. J. Immunol. 1991, 147, 2902-2906. [PubMed]

42. Iizuka, J.; Katagiri, Y.; Tada, N.; Murakami, M.; Ikeda, T.; Sato, M.; Hirokawa, K.; Okada, S.; Hatano, M.; Tokuhisa, T.; et al. Introduction of an osteopontin gene confers the increase in B1 cell population and the production of anti-DNA autoantibodies. Lab. Investig. 1998, 78, 1523-1533. [PubMed]

43. Kitagori, K.; Yoshifuji, H.; Oku, T.; Sasaki, C.; Miyata, H.; Mori, K.P.; Nakajima, T.; Ohmura, K.; Kawabata, D.; Yukawa, N.; et al. Cleaved Form of Osteopontin in Urine as a Clinical Marker of Lupus Nephritis. PLoS ONE 2016, 11, e0167141. [CrossRef] [PubMed]

44. Clemente, N.; Raineri, D.; Cappellano, G.; Boggio, E.; Favero, F.; Soluri, M.F.; Dianzani, C.; Comi, C.; Dianzani, U.; Chiocchetti, A. Osteopontin Bridging Innate and Adaptive Immunity in Autoimmune Diseases. J. Immunol. Res. 2016, 2016, 7675437. [CrossRef] [PubMed] 
45. Clemente, N.; Comi, C.; Raineri, D.; Cappellano, G.; Vecchio, D.; Orilieri, E.; Gigliotti, C.L.; Boggio, E.; Dianzani, C.; Sorosina, M.; et al. Role of Anti-Osteopontin Antibodies in Multiple Sclerosis and Experimental Autoimmune Encephalomyelitis. Front. Immunol. 2017, 8, 321. [CrossRef] [PubMed]

46. Dianzani, C.; Bellavista, E.; Liepe, J.; Verderio, C.; Martucci, M.; Santoro, A.; Chiocchetti, A.; Gigliotti, C.L.; Boggio, E.; Ferrara, B.; et al. Extracellular proteasome-osteopontin circuit regulates cell migration with implications in multiple sclerosis. Sci. Rep. 2017, 7, 43718. [CrossRef] [PubMed]

47. Ma, N.; He, Y.; Xiao, H.; Han, G.; Chen, G.; Wang, Y.; Wang, K.; Hou, C.; Yang, X.; Marrero, B.; et al. BAFF maintains T-cell survival by inducing OPN expression in B cells. Mol. Immunol. 2014, 57, 129-137. [CrossRef] [PubMed]

48. Chiche, J.; Rouleau, M.; Gounon, P.; Brahimi-Horn, M.C.; Pouyssegur, J.; Mazure, N.M. Hypoxic enlarged mitochondria protect cancer cells from apoptotic stimuli. J. Cell. Physiol. 2010, 222, 648-657. [CrossRef] [PubMed]

49. Lagergren, J.; Bergstrom, R.; Lindgren, A.; Nyren, O. Symptomatic gastroesophageal reflux as a risk factor for esophageal adenocarcinoma. N. Engl. J. Med. 1999, 340, 825-831. [CrossRef] [PubMed]

50. Shaheen, N.J.; Richter, J.E. Barrett's oesophagus. Lancet 2009, 373, 850-861. [CrossRef]

51. Kim, S.M.; Park, Y.Y.; Park, E.S.; Cho, J.Y.; Izzo, J.G.; Zhang, D.; Kim, S.B.; Lee, J.H.; Bhutani, M.S.; Swisher, S.G.; et al. Prognostic biomarkers for esophageal adenocarcinoma identified by analysis of tumor transcriptome. PLoS ONE 2010, 5, e15074. [CrossRef] [PubMed]

52. Lin, J.; Myers, A.L.; Wang, Z.; Nancarrow, D.J.; Ferrer-Torres, D.; Handlogten, A.; Leverenz, K.; Bao, J.; Thomas, D.G.; Wang, T.D.; et al. Osteopontin (OPN/SPP1) isoforms collectively enhance tumor cell invasion and dissemination in esophageal adenocarcinoma. Oncotarget 2015, 6, 22239-22257. [CrossRef] [PubMed]

53. Miller, C.T.; Lin, L.; Casper, A.M.; Lim, J.; Thomas, D.G.; Orringer, M.B.; Chang, A.C.; Chambers, A.F.; Giordano, T.J.; Glover, T.W. Genomic amplification of MET with boundaries within fragile site FRA7G and upregulation of MET pathways in esophageal adenocarcinoma. Oncogene 2006, 25, 409418. [CrossRef] [PubMed]

54. Correa, P.; Haenszel, W.; Cuello, C.; Zavala, D.; Fontham, E.; Zarama, G.; Tannenbaum, S.; Collazos, T.; Ruiz, B. Gastric precancerous process in a high risk population: Cohort follow-up. Cancer Res. 1990, 50, 4737-4740. [PubMed]

55. Kinoshita, H.; Hayakawa, Y.; Koike, K. Metaplasia in the Stomach-Precursor of Gastric Cancer? Int. J. Mol. Sci. 2017, 18, 2063. [CrossRef] [PubMed]

56. Rollo, E.E.; Laskin, D.L.; Denhardt, D.T. Osteopontin inhibits nitric oxide production and cytotoxicity by activated RAW264.7 macrophages. J. Leukoc. Biol. 1996, 60, 397-404. [PubMed]

57. Chang, W.L.; Yang, H.B.; Cheng, H.C.; Chuang, C.H.; Lu, P.J.; Sheu, B.S. Increased gastric osteopontin expression by Helicobacter pylori Infection can correlate with more severe gastric inflammation and intestinal metaplasia. Helicobacter 2011, 16, 217-224. [CrossRef] [PubMed]

58. Chang, W.L.; Lin, M.Y.; Kuo, H.Y.; Yang, H.B.; Cheng, H.C.; Lu, C.C.; Sheu, B.S. Osteopontin polymorphism increases gastric precancerous intestinal metaplasia susceptibility in Helicobacter pylori infected male. Future Oncol. 2017, 13, 1415-1425. [CrossRef] [PubMed]

59. Song, G.; Ming, Y.; Mao, Y.; Bao, S.; Ouyang, G. Osteopontin prevents curcumin-induced apoptosis and promotes survival through Akt activation via $\alpha v \beta 3$ integrins in human gastric cancer cells. Exp. Biol. Med. (Maywood) 2008, 233, 1537-1545. [CrossRef] [PubMed]

60. Lee, J.L.; Wang, M.J.; Sudhir, P.R.; Chen, G.D.; Chi, C.W.; Chen, J.Y. Osteopontin promotes integrin activation through outsidein and inside-out mechanisms: OPN-CD44V interaction enhances survival in gastrointestinal cancer cells. Cancer Res. 2007, 67, 2089-2097. [CrossRef] [PubMed]

61. Gong, M.; Lu, Z.; Fang, G.; Bi, J.; Xue, X. A small interfering RNA targeting osteopontin as gastric cancer therapeutics. Cancer Lett. 2008, 272, 148-159. [CrossRef] [PubMed]

62. Lee, S.H.; Park, J.W.; Go, D.M.; Kim, H.K.; Kwon, H.J.; Han, S.U.; Kim, D.Y. Ablation of osteopontin suppresses $N$-methyl- $N$-nitrosourea and Helicobacter pylori-induced gastric cancer development in mice. Carcinogenesis 2015, 36, 1550-1560. [PubMed]

63. Tang, R.; Yang, G.; Zhang, S.; Wu, C.; Chen, M. Opposite effects of interferon regulatory factor 1 and osteopontin on the apoptosis of epithelial cells induced by TNF- $\alpha$ in inflammatory bowel disease. Inflamm. Bowel Dis. 2014, 20, 1950-1961. [CrossRef] [PubMed] 
64. Toyonaga, T.; Nakase, H.; Ueno, S.; Matsuura, M.; Yoshino, T.; Honzawa, Y.; Itou, A.; Namba, K.; Minami, N.; Yamada, S.; et al. Osteopontin Deficiency Accelerates Spontaneous Colitis in Mice with Disrupted Gut Microbiota and Macrophage Phagocytic Activity. PLoS ONE 2015, 10, e0135552. [CrossRef] [PubMed]

65. Heilmann, K.; Hoffmann, U.; Witte, E.; Loddenkemper, C.; Sina, C.; Schreiber, S.; Hayford, C.; Holzlöhner, P.; Wolk, K.; Tchatchou, E.; et al. Osteopontin as two-sided mediator of intestinal inflammation. J. Cell. Mol. Med. 2009, 13, 1162-1174. [CrossRef] [PubMed]

66. Zhong, J.; Eckhardt, E.R.; Oz, H.S.; Bruemmer, D.; de Villiers, W.J. Osteopontin deficiency protects mice from Dextran sodium sulfate-induced colitis. Inflamm. Bowel Dis. 2006, 12, 790-796. [CrossRef] [PubMed]

67. Mannick, E.E.; Cote, R.L.; Schurr, J.R.; Krowicka, H.S.; Sloop, G.D.; Zapata-Velandia, A.; Correa, H.; Ruiz, B.; Horswell, R.; Lentz, J.J. Altered phenotype of dextran sulfate sodium colitis in interferon regulatory factor-1 knock-out mice. J. Gastroenterol. Hepatol. 2005, 20, 371-380. [CrossRef] [PubMed]

68. Arai, M.; Yokosuka, O.; Kanda, T.; Fukai, K.; Imazeki, F.; Muramatsu, M.; Seki, N.; Miyazaki, M.; Ochiai, T.; Hirasawa, H.; et al. Serum osteopontin levels in patients with acute liver dysfunction. Scand. J. Gastroenterol. 2006, 41, 102-110. [CrossRef] [PubMed]

69. Srungaram, P.; Rule, J.A.; Yuan, H.J.; Reimold, A.; Dahl, B.; Sanders, C.; Lee, W.M.; Acute Liver Failure Study Group. Plasma osteopontin in acute liver failure. Cytokine 2015, 73, 270-276. [CrossRef] [PubMed]

70. Yilmaz, Y.; Ozturk, O.; Alahdab, Y.O.; Senates, E.; Colak, Y.; Doganay, H.L.; Coskunpinar, E.; Oltulu, Y.M.; Eren, F.; Atug, O.; et al. Serum osteopontin levels as a predictor of portal inflammation in patients with nonalcoholic fatty liver disease. Dig. Liver Dis. 2013, 45, 58-62. [CrossRef] [PubMed]

71. Seth, D.; Leo, M.A.; McGuinness, P.H.; Lieber, C.S.; Brennan, Y.; Williams, R.; Wang, X.M.; McCaughan, G.W.; Gorrell, M.D.; Haber, P.S. Gene expression profiling of alcoholic liver disease in the baboon (Papio hamadryas) and human liver. Am. J. Pathol. 2003, 163, 2303-2317. [CrossRef]

72. Zhao, L.; Li, T.; Wang, Y.; Pan, Y.; Ning, H.; Hui, X.; Xie, H.; Wang, J.; Han, Y.; Liu, Z.; et al. Elevated plasma osteopontin level is predictive of cirrhosis in patients with hepatitis B infection. Int. J. Clin. Pract. 2008, 62, 1056-1062. [CrossRef] [PubMed]

73. Huang, W.; Zhu, G.; Huang, M.; Lou, G.; Liu, Y.; Wang, S. Plasma osteopontin concentration correlates with the severity of hepatic fibrosis and inflammation in HCV-infected subjects. Clin. Chim. Acta 2010, 411, 675-678. [CrossRef] [PubMed]

74. Matsue, Y.; Tsutsumi, M.; Hayashi, N.; Saito, T.; Tsuchishima, M.; Toshikuni, N.; Arisawa, T.; George, J. Serum osteopontin predicts degree of hepatic fibrosis and serves as a biomarker in patients with hepatitis $\mathrm{C}$ virus infection. PLoS ONE 2015, 10, e0118744. [CrossRef] [PubMed]

75. Harada, K.; Ozaki, S.; Sudo, Y.; Tsuneyama, K.; Ohta, H.; Nakanuma, Y. Osteopontin is involved in the formation of epithelioid granuloma and bile duct injury in primary biliary cirrhosis. Pathol. Int. 2003, 53, 8-17. [CrossRef] [PubMed]

76. Seth, D.; Duly, A.; Kuo, P.C.; McCaughan, G.W.; Haber, P.S. Osteopontin is an important mediator of alcoholic liver disease via hepatic stellate cell activation. World J. Gastroenterol. 2014, 20, 13088-13104. [CrossRef] [PubMed]

77. Geisler, F.; Strazzabosco, M. Emerging roles of Notch signaling in liver disease. Hepatology 2015, 61, 382-392. [CrossRef] [PubMed]

78. Williams, M.J.; Clouston, A.D.; Forbes, S.J. Links between hepatic fibrosis, ductular reaction, and progenitor cell expansion. Gastroenterology 2014, 146, 349-356. [CrossRef] [PubMed]

79. Wang, X.; Lopategi, A.; Ge, X.; Lu, Y.; Kitamura, N.; Urtasun, R.; Leung, T.M.; Fiel, M.I.; Nieto, N. Osteopontin induces ductular reaction contributing to liver fibrosis. Gut 2014, 63, 1805-1818. [CrossRef] [PubMed]

80. Banerjee, A.; Burghardt, R.C.; Johnson, G.A.; White, F.J.; Ramaiah, S.K. The temporal expression of osteopontin (SPP-1) in the rodent model of alcoholic steatohepatitis: A potential biomarker. Toxicol. Pathol. 2006, 34, 373-384. [CrossRef] [PubMed]

81. Lazaro, R.; Wu, R.; Lee, S.; Zhu, N.L.; Chen, C.L.; French, S.W.; Xu, J.; Machida, K.; Tsukamoto, H. Osteopontin deficiency does not prevent but promotes alcoholic neutrophilic hepatitis in mice. Hepatology 2015, 61, 129-140. [CrossRef] [PubMed]

82. Ge, X.; Leung, T.M.; Arriazu, E.; Lu, Y.; Urtasun, R.; Christensen, B.; Fiel, M.I.; Mochida, S.; Sørensen, E.S.; Nieto, N. Osteopontin binding to lipopolysaccharide lowers tumor necrosis factor- $\alpha$ and prevents early alcohol-induced liver injury in mice. Hepatology 2014, 59, 1600-1616. [CrossRef] [PubMed] 
83. Wang, G.; Chen, S.; Zhao, C.; Li, X.; Zhao, W.; Yang, J.; Chang, C.; Xu, C. Comparative analysis of gene expression profiles of OPN signaling pathway in four kinds of liver diseases. J. Genet. 2016, 95, 741-750. [CrossRef] [PubMed]

84. Wang, G.; Zhao, C.; Chen, S.; Li, X.; Zhang, L.; Chang, C.; Xu, C. A preliminary in vivo study of the effects of OPN on rat liver regeneration induced by partial hepatectomy. Mol. Biol. Rep. 2016, 43, 1371-1382. [CrossRef] [PubMed]

85. Nagoshi, S. Osteopontin: Versatile modulator of liver disease. Hepatol. Res. 2014, 44, 22-30. [CrossRef] [PubMed]

86. Pan, H.W.; Ou, Y.H.; Peng, S.Y.; Liu, S.H.; Lai, P.L.; Lee, P.H.; Sheu, J.C.; Chen, C.L.; Hsu, H.C. Overexpression of osteopontin is associated with intrahepatic metastasis, early recurrence, and poorer prognosis of surgically resected hepatocellular carcinoma. Cancer 2003, 98, 119-127. [CrossRef] [PubMed]

87. Yu, M.C.; Lee, Y.S.; Lin, S.E.; Wu, H.Y.; Chen, T.C.; Lee, W.C.; Chen, M.F.; Tsai, C.N. Recurrence and poor prognosis following resection of small hepatitis B-related hepatocellular carcinoma lesions are associated with aberrant tumor expression profiles of glypican 3 and osteopontin. Ann. Surg. Oncol. 2012, 19, S455-S463. [CrossRef] [PubMed]

88. Zhao, J.; Dong, L.; Lu, B.; Wu, G.; Xu, D.; Chen, J.; Li, K.; Tong, X.; Dai, J.; Yao, S.; et al. Down-regulation of osteopontin suppresses growth and metastasis of hepatocellular carcinoma via induction of apoptosis. Gastroenterology 2008, 135, 956-968. [CrossRef] [PubMed]

89. Lee, S.H.; Park, J.W.; Woo, S.H.; Go, D.M.; Kwon, H.J.; Jang, J.J.; Kim, D.Y. Suppression of osteopontin inhibits chemically induced hepatic carcinogenesis by induction of apoptosis in mice. Oncotarget 2016, 7, 87219-87231. [CrossRef] [PubMed]

90. Lee, K.T.; Liu, T.S. Altered mucin gene expression in stone-containing intrahepatic bile ducts and cholangiocarcinomas. Dig. Dis. Sci. 2001, 46, 2166-2172. [CrossRef] [PubMed]

91. Nakanuma, Y.; Yamaguchi, K.; Ohta, G.; Terada, T. Pathologic features of hepatolithiasis in Japan. Hum. Pathol. 1998, 19, 1181-1186. [CrossRef]

92. Nakanuma, Y.; Sasaki, M.; Terada, T.; Harada, K. Intrahepatic peribiliary glands of humans. II. Pathological spectrum. J. Gastroenterol. Hepatol. 1994, 9, 80-86. [CrossRef] [PubMed]

93. Yamamoto, K. Intrahepatic periductal glands and their significance in primary intrahepatic lithiasis. Jpn. J. Surg. 1982, 12, 163-170. [CrossRef] [PubMed]

94. Kim, B.S.; Joo, S.H.; Lim, S.J.; Joo, K.R. Osteopontin Expression in Patients with Hepatolith. Indian J. Surg. 2015, 77, 551-556. [CrossRef] [PubMed]

95. Nakai, A.; Imano, M.; Takeyama, Y.; Shiozaki, H.; Ohyanagi, H. An immunohistochemical study of osteopontin in hepatolithiasis. J. Hepatobiliary Pancreat. Surg. 2008, 15, 615-621. [CrossRef] [PubMed]

96. Terashi, T.; Aishima, S.; Taguchi, K.; Asayama, Y.; Sugimachi, K.; Matsuura, S.; Shimada, M.; Maehara, S.; Maehara, Y.; Tsuneyoshi, M. Decreased expression of osteopontin is related to tumor aggressiveness and clinical outcome of intrahepatic cholangiocarcinoma. Liver Int. 2004, 24, 38-45. [CrossRef] [PubMed]

97. Sulpice, L.; Rayar, M.; Desille, M.; Turlin, B.; Fautrel, A.; Boucher, E.; Llamas-Gutierrez, F.; Meunier, B.; Boudjema, K.; Clément, B.; et al. Molecular profiling of stroma identifies osteopontin as an independent predictor of poor prognosis in intrahepatic cholangiocarcinoma. Hepatology 2013, 58, 1992-2000. [CrossRef] [PubMed]

98. Zhang, J.; Jiao, J.; Cermelli, S.; Muir, K.; Jung, K.H.; Zou, R.; Rashid, A.; Gagea, M.; Zabludoff, S.; Kalluri, R.; et al. miR-21 Inhibition Reduces Liver Fibrosis and Prevents Tumor Development by Inducing Apoptosis of CD24+ Progenitor Cells. Cancer Res. 2015, 75, 1859-1867. [CrossRef] [PubMed]

99. Razumilava, N.; Gores, G.J. Cholangiocarcinoma. Lancet 2014, 383, 2168-2179. [CrossRef]

100. Rizvi, S.; Gores, G.J. Pathogenesis, diagnosis, and management of cholangiocarcinoma. Gastroenterology 2013, 145, 1215-1229. [CrossRef] [PubMed]

101. Tanaka, M.; Tanaka, H.; Tsukuma, H.; Ioka, A.; Oshima, A.; Nakahara, T. Risk factors for intrahepatic cholangiocarcinoma: A possible role of hepatitis B virus. J. Viral Hepat. 2010, 17, 742-748. [CrossRef] [PubMed]

102. Fickert, P.; Thueringer, A.; Moustafa, T.; Silbert, D.; Gumhold, J.; Tsybrovskyy, O.; Lebofsky, M.; Jaeschke, H.; Denk, H.; Trauner, M. The role of osteopontin and tumor necrosis factor $\alpha$ receptor- 1 in xenobiotic-induced cholangitis and biliary fibrosis in mice. Lab. Investig. 2010, 90, 844-852. [CrossRef] [PubMed] 
103. Pereira, T.A.; Syn, W.K.; Machado, M.V.; Vidigal, P.V.; Resende, V.; Voieta, I.; Xie, G.; Otoni, A.; Souza, M.M.; Santos, E.T.; et al. Schistosome-induced cholangiocyte proliferation and osteopontin secretion correlate with fibrosis and portal hypertension in human and murine schistosomiasis mansoni. Clin. Sci. 2015, 129, 875-883. [CrossRef] [PubMed]

104. Tannapfel, A.; Sommerer, F.; Benicke, M.; Katalinic, A.; Uhlmann, D.; Witzigmann, H.; Hauss, J.; Wittekind, C. Mutations of the BRAF gene in cholangiocarcinoma but not in hepatocellular carcinoma. Gut 2003, 52, 706-712. [CrossRef] [PubMed]

105. Zheng, T.; Hong, X.; Wang, J.; Pie, T.; Liang, Y.; Yin, D.; Song, R.; Song, X.; Lu, Z.; Qi, S.; et al. Gankyrin promotes tumor growth and metastasis through activation of IL-6/STAT3 signaling in human cholangiocarcinoma. Hepatology 2014, 59, 935-946. [CrossRef] [PubMed]

106. Isomoto, H.; Mott, J.L.; Kobayashi, S.; Warneburg, N.W.; Bronk, S.F.; Haan, S.; Gores, G.J. Sustained IL-6/STAT-3 signaling in cholangiocarcinoma cells due to SOCS-3 epigenetic silencing. Gastroenterology 2007, 132, 384-396. [CrossRef] [PubMed]

107. Lu, D.; Han, C.; Wu, T. 15-hydroxyprostaglandin dehydrogenase-derived 15-keto-prostaglandin E2 inhibits cholangiocarcinoma cell growth through interaction with peroxisome proliferator-activated receptor- $\gamma$, SMAD2/3, and TAP63 proteins. J. Biol. Chem. 2013, 288, 19484-19502. [CrossRef] [PubMed]

108. Techasen, A.; Namwat, N.; Loilome, W.; Bungkanjana, P.; Khuntikeo, N.; Puapairoj, A.; Jearanaikoon, P.; Saya, H.; Yongvanit, P. Tumor necrosis factor- $\alpha$ (TNF- $\alpha)$ stimulates the epithelial-mesenchymal transition regulator Snail in cholangiocarcinoma. Med. Oncol. 2012, 29, 3083-3091. [CrossRef] [PubMed]

109. Huang, Q.X.; Cui, J.Y.; Ma, H.; Jia, X.M.; Huang, F.L.; Jiang, L.X. Screening of potential biomarkers for cholangiocarcinoma by integrated analysis of microarray data sets. Cancer Gene Ther. 2016, 23, 48-53. [CrossRef] [PubMed]

110. Laohaviroj, M.; Chamgramol, Y.; Pairojkul, C.; Mulvenna, J.; Sripa, B. Clinicopathological Significance of Osteopontin in Cholangiocarcinoma Cases. Asian Pac. J. Cancer Prev. 2016, 17, 201-205. [CrossRef] [PubMed]

111. Loosen, S.H.; Roderburg, C.; Kauertz, K.L.; Pombeiro, I.; Leyh, C.; Benz, F.; Vucur, M.; Longerich, T.; Koch, A.; Braunschweig, T.; et al. Elevated levels of circulating osteopontin are associated with a poor survival after resection of cholangiocarcinoma. J. Hepatol. 2017, 67, 749-757. [CrossRef] [PubMed]

112. Lustri, A.M.; Di Matteo, S.; Fraveto, A.; Costantini, D.; Cantafora, A.; Napoletano, C.; Bragazzi, M.C.; Giuliante, F.; De Rose, A.M.; Berloco, P.B.; et al. TGF- $\beta$ signaling is an effective target to impair survival and induce apoptosis of human cholangiocarcinoma cells: A study on human primary cell cultures. PLoS ONE 2017, 12, e0183932. [CrossRef] [PubMed]

113. Isomoto, H.; Kobayashi, S.; Werneburg, N.W.; Bronk, S.F.; Guicciardi, M.E.; Frank, D.A.; Gores, G.J. Interleukin 6 upregulates myeloid cell leukemia-1 expression through a STAT3 pathway in cholangiocarcinoma cells. Hepatology 2005, 42, 1329-1338. [CrossRef] [PubMed]

114. Takemoto, M.; Yokote, K.; Yamazaki, M.; Ridall, A.L.; Butler, W.T.; Matsumoto, T.; Tamura, K.; Saito, Y.; Mori, S. Enhanced expression of osteopontin by high glucose in cultured rat aortic smooth muscle cells. Biochem. Biophys. Res. Commun. 1999, 258, 722-726. [CrossRef] [PubMed]

115. Hsieh, M.S.; Zhong, W.B.; Yu, S.C.; Lin, J.Y.; Chi, W.M.; Lee, H.M. Dipyridamole suppresses high glucose-induced osteopontin secretion and mRNA expression in rat aortic smooth muscle cells. Circ. J. 2010, 74, 1242-1250. [CrossRef] [PubMed]

116. Katakam, A.K.; Chipitsyna, G.; Gong, Q.; Vancha, A.R.; Gabß, J.; Arafat, H.A. Streptozotocin (STZ) mediates acute upregulation of serum and pancreatic osteopontin (OPN): A novel islet-protective effect of OPN through inhibition of STZ-induced nitric oxide production. J. Endocrinol. 2005, 187, 237-247. [CrossRef] [PubMed]

117. Arafat, H.A.; Katakam, A.K.; Chipitsyna, G.; Gong, Q.; Vancha, A.R.; Gabß, J.; Dafoe, D.C. Osteopontin protects the islets and $\beta$-cells from interleukin-1 $\beta$-mediated cytotoxicity through negative feedback regulation of nitric oxide. Endocrinology 2007, 148, 575-584. [CrossRef] [PubMed]

118. Lyssenko, V.; Eliasson, L.; Kotova, O.; Pilgaard, K.; Wierup, N.; Salehi, A.; Wendt, A.; Jonsson, A.; De Marinis, Y.Z.; Berglund, L.M.; et al. Pleiotropic effects of GIP on islet function involve osteopontin. Diabetes 2011, 60, 2424-2433. [CrossRef] [PubMed]

119. Nakamura, M.; Oka, M.; Iizuka, N.; Kawauchi, S.; Gondo, T.; Ueno, T.; Tangoku, A. Osteopontin expression in chronic pancreatitis. Pancreas 2002, 25, 182-187. [CrossRef] [PubMed] 
120. Takada, H.; Nakazawa, T.; Ohara, H.; Ando, T.; Hayashi, K.; Naito, I.; Okumura, F.; Tanaka, H.; Yamada, T.; Takahashi, S.; et al. Role of osteopontin in calcification in autoimmune pancreatitis. Dig. Dis. Sci. 2009, 54, 793-801. [CrossRef] [PubMed]

121. Rychlíková, J.; Vecka, M.; Jáchymová, M.; Macášek, J.; Hrabák, P.; Zeman, M.; Vávrová, L.; Řoupal, J.; Krechler, T.; Ák, A. Osteopontin as a discriminating marker for pancreatic cancer and chronic pancreatitis. Cancer Biomark. 2016, 17, 55-65. [CrossRef] [PubMed]

122. Kolb, A.; Kleeff, J.; Guweidhi, A.; Esposito, I.; Giese, N.A.; Adwan, H.; Giese, T.; Büchler, M.W.; Berger, M.R. Friess, H. Osteopontin influences the invasiveness of pancreatic cancer cells and is increased in neoplastic and inflammatory conditions. Cancer Biol. Ther. 2005, 4, 740-746. [CrossRef] [PubMed]

123. Li, J.J.; Li, H.Y.; Gu, F. Diagnostic significance of serum osteopontin level for pancreatic cancer: A meta-analysis. Genet. Test. Mol. Biomark. 2014, 18, 580-586. [CrossRef] [PubMed]

124. Ito, M.; Makino, N.; Matsuda, A.; Ikeda, Y.; Kakizaki, Y.; Saito, Y.; Ueno, Y.; Kawata, S. High Glucose Accelerates Cell Proliferation and Increases the Secretion and mRNA Expression of Osteopontin in Human Pancreatic Duct Epithelial Cells. Int. J. Mol. Sci. 2017, 18, 807. [CrossRef] [PubMed]

125. Collins, A.L.; Rock, J.; Malhotra, L.; Frankel, W.L.; Bloomston, M. Osteopontin expression is associated with improved survival in patients with pancreatic adenocarcinoma. Ann. Surg. Oncol. 2012, 19, 2673-2678. [CrossRef] [PubMed]

126. Weber, C.E.; Erşahin, Ç.H.; Kuo, P.C.; Mi, Z. Pancreatic Cancer and Osteopontin: The Relationship Remains Unclear. Pancreas 2016, 45, e35-e36. [CrossRef] [PubMed]

127. Ferrara, J.L.; Levine, J.E.; Reddy, P.; Holler, E. Graft-versus-host disease. Lancet 2009, 373, $1550-1561$. [CrossRef]

128. Markey, K.A.; MacDonald, K.P.; Hill, G.R. The biology of graft-versus-host disease: Experimental systems instructing clinical practice. Blood 2014, 124, 354-362. [CrossRef] [PubMed]

129. Zhao, F.; Zhang, Y.; Wang, H.; Jin, M.; He, S.; Shi, Y.; Guo, Y.; Zhang, Y. Blockade of osteopontin reduces alloreactive CD8+T cell-mediated graft-versus-host disease. Blood 2011, 117, 1723-1733. [CrossRef] [PubMed]

130. Kawakami, K.; Minami, N.; Matsuura, M.; Iida, T.; Toyonaga, T.; Nagaishi, K.; Arimura, Y.; Fujimiya, M.; Uede, T.; Nakase, H. Osteopontin attenuates acute gastrointestinal graft-versus-host disease by preventing apoptosis of intestinal epithelial cells. Biochem. Biophys. Res. Commun. 2017, 485, 468475. [CrossRef] [PubMed] 